\title{
The Changing Competition Between Commercial Banks and Thrift Institutions for Deposits
}

\author{
JEAN M. LOVATI
}

(ㄹ

OMMERCIAL banks and thrift institutions (savings and loan associations and mutual savings banks) compete in various ways for deposits of customers. Commercial banks offer a full range of services and attract customers with "one-stop" banking. One of these services is the checking account. This type of account provides depositors with a convenient and widely accepted means of making third party payments, but because of Federal regulations, deposits in these accounts do not explicitly bear interest.

Thrift institutions, on the other hand, historically have not been able to offer checking accounts. If depositors of a thrift institution desire to make payments to third parties, they either withdraw cash from their savings accounts or withdraw funds in the form of checks written by the thrift institution on its demand deposit account at a commercial bank. While the depositors may find this method of payment less convenient than using a checking account, they earn interest on their deposited funds. Moreover, the rate of interest that thrift institutions are allowed to pay on savings deposits is somewhat higher than that permitted for commercial banks.

Recent competition for deposits between commercial banks and thrift institutions has been undergoing rapid change and intensification. Thrift institutions (thrifts) have started to offer new services which remove much of the inconvenience associated with making payments from savings accounts. As a consequence, savings accounts at thrifts are now becoming more like checking accounts at commercial banks.

This article describes changes occurring at some savings and loan associations and mutual savings banks which, by making deposit accounts at these institutions more attractive for making payments, enable the institutions to compete more effectively with commercial banks for customers' deposits. Innovations at savings and loan associations and mutual savings banks are discussed in the first sections of the paper. The impact of the changes on competition between commercial banks and thrifts is examined in the next section. The response of commercial banks and their regulators to the challenge posed by the increased competition is then described.

\section{NeV SERVICES AT

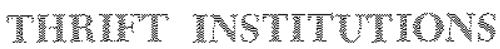

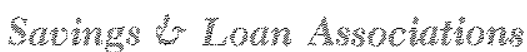

The Federal Home Loan Bank Board (FHLBB), which regulates Federally chartered savings and loan associations ( $S \&$ Ls), has encouraged greater competition between $S \& \mathrm{Ls}$ and commercial banks by allowing Federal $S \&$ Ls to offer a number of new services to their customers. In January 1974, the FHLBB adopted a temporary regulation which permits Federal S \& Ls to operate experimental place $\circ$ of -business funds transfer systems, These systems allow customers to conduct financial transactions through the use of electronic signals generated by on-line computer terminals as well as off-line automated teller machines. ${ }^{1}$ The terminals, which are called remote service units, allow depositors to conduct transactions with their $S$ \& Ls at places of business other than the associations' offices. The remote service units, which may be

\footnotetext{
1Transactions initiated through the use of on-line computer terminals are instantly communicated to and verified by the $S \& L$ is central computer. Off-line facilities generally are not connected directly to the computer of the $S \& L$; transactions initiated at these terminals are recorded on magnetic tape or a like medium which is snbsequently delivered to and read by the $S$ \& L's computer.
} 
shared with other Federally insured financial institutions, are not treated as branch or satellite offices of the $S$ \& Ls by the FHLBB.

Also, in January 1974 the funds transfer system initiated by the First Federal Savings and Loan Association, Lincoln, Nebraska was approved under the new regulation. ${ }^{2}$ This place-of-business system allows depositors of First Federal to make deposits to or withdrawals from their interest-bearing savings accounts at two Hinky Dinky supermarkets in Lincoln. Transactions are made with the use of plastic cards on which account information is encoded on magnetic stripes. At the supermarket, Hinky Dinky employees transmit transaction data to First Federal's central computer which records the actions. Settlement is accomplished electronically by entries to the accounts of depositors and Hinky Dinky at First Federal. At the supermarket, money is accepted from or disbursed to the customer-depositor by the employees through cash drawers maintained by Hinky Dinky for completion of the physical part of the transactions.

Within two months after the installation of the system, legal action interrupted this service. The state of Nebraska first brought suit against Hinky Dinky on the grounds that the supermarket was offering banking services without a license. The Nebraska Banking Association also brought suit, charging that First Federal was violating the state's anti-branching laws. With litigation still pending, the savings and loan services in the two Hinky Dinky stores resumed operation in September of last year. Since resumption of the service, First Federal has installed its funds transfer units in three additional Hinky Dinky stores in Lincoln and has received FHLBB approval to expand the service to 19 of the supermarket cham's stores in eastern Nebraska.

In April of last year, the state of Washington enacted legislation which allows state chartered commercial banks, mutual savings banks, and $\mathrm{S} \& \mathrm{~L}$ s to establish any number of unmanned facilities throughout the state, provided that those operating the facilities share the costs and operation of the terminals when asked to do so by the state authorities. Commercial banks are required to share facifities with other commercial banks and have the option of sharing with thrift institutions. Thrifts are permitted, but not required, to share facilities. These facilities are not considered branches under Washington law.

"Nebraska S \& L Begins Point-of-Sale EFTS;" American Banker, January 16, 1974.
An electronic facility began operation in July 1974 on a 24-hour basis in Bellevue, Washington." In this case, the unit is shared by four mutual savings banks, ten Federal savings and loan associations, and two state-chartered S \& Ls. Unlike the Hinky Dinky ter. minal, this automated teller machine is unmanned and is operated by the depositor, independent of any business. Cash disbursements are made through the use of automatic cash dispensers which are activated by the depositor's magnetic card. Deposits are handled in a manner similar to that used for night depositories.

Other S \& Ls across the country have also initiated funds transfer systems, implementing place-of-business terminals and automated teller machines similar to those just described. Because of the rapid development and implementation of these systems in many states, only two have been described here in detail. A list of the savings and loan associations which have received FHLBB approval for electronic transfer systems is presented in Exhibit I.

In addition to these electronic innovations, other changes have taken place which permit savings and loan associations to compete more effectively for deposits. One such change involves the bill payment services which $S$ \& Ls are able to offer. At the depositor's request, Federal $S$ \& Ls may honor nontransferable orders to transfer funds, periodically or otherwise, from the depositor's savings account to third parties. In the past, such payments were limited to housing-related items and loans on these items, such as payments on mortgages, rent, taxes, utilities, and home improvements. The FHLBB recently removed the housing-related restriction, thus allowing Federal savings and loan associations to offer a full range of bill payment services.

In December of last year, the FHLBB also adopted a regulation which gives depositors traveling more than 50 miles from their home access to their savings account balances through any other Federally-insured savings and loan association by means of a Travelers Convenience Withdrawal. The $S \& \mathrm{~L}$ at which a customer has requested such a withdrawal notifies, by wire or telephone, the $S \& \mathrm{~L}$ at which the customer has a deposit account to deduct the amount of the withdrawal from that account. Funds are then disbursed by the cooperating savings and loan association, and the $S \&$ Ls which have chosen to offer this service make settlements among themselves.

"15 Washington State Thrifts to Test Electrotic Teller," American Banker, February 21, 1974. 
+xibil

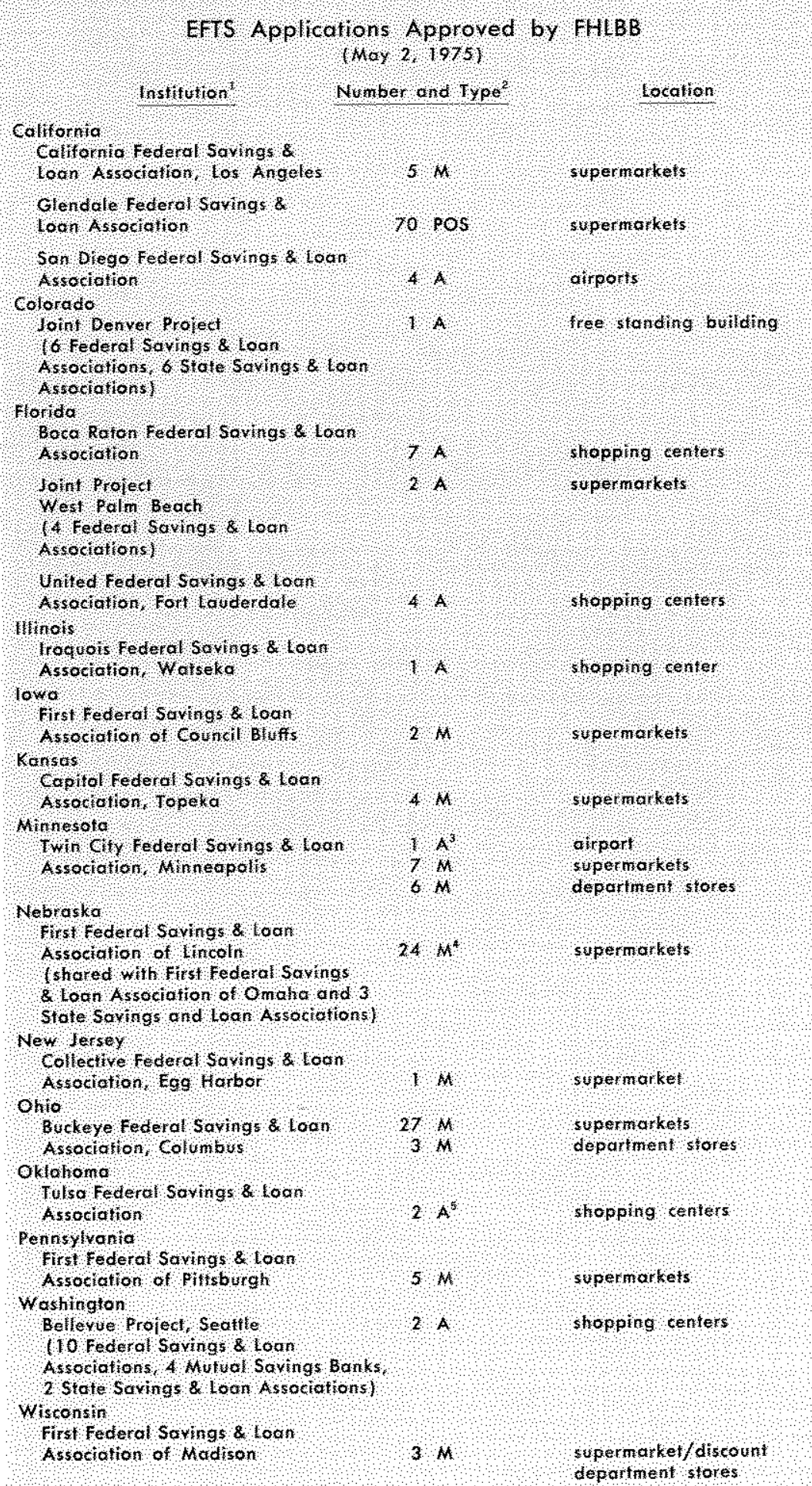

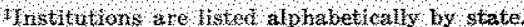

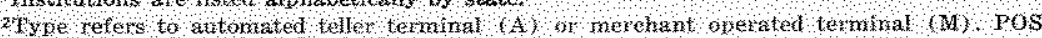

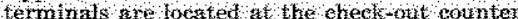

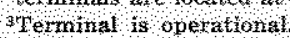

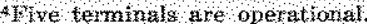

50 te termenal oneratoral

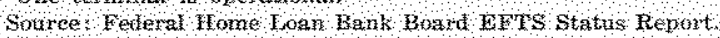

\section{Inten Sawng Bang}

Financial institutions in New England have attracted widespread attention by offering Negotiable Order of Withdrawal (NOW) accounts. Unlike conventional savings accounts, NOW accounts permit depositors to make checklike withdrawals from their interestbearing savings accounts for making payments to third parties. The withdrawal orders are cleared through the Federal Reserve System's check clearing facilities by means of special touting numbers which are assigned to the thrift institutions.

This type of account was first offered in 1972 by the Consumers Savings Bank of Worcester, Massachusetts, and was rapidly initiated at other savings banks in Massachusetts and New Hampshire. At the time, commercial banks in those states opposed the use of NOWs and urged a ban on them by Congress. Legm islation was subsequently enacted which limits the use of NOW accounts to these two states, but allows not only mutual savings banks but also commercial banks and savings and loan associations within these states to offer such accounts.

This legislation, which permitted an additional 427 depository financial institutions to offer NOW accounts, affected the competitive balance among institutions in the two states. Of these newly eligible institutions, commercial banks introduced the majority of the new NOW accounts. The 200 mutual savings banks in Massachusetts and New Hampshire, which were previously the only financial institutions permitted to offer NoW accounts, experienced a decline in their NOW account deposits during the initial implementation of the legislation. As more financial institutions began to offer NOW accounts, service charges on drafts from the accounts were reduced or eliminated by many

\footnotetext{
${ }^{*}$ Early History and Initial Impact of NoW Accounts," New England Economic Revieu (January/February 1975), pp. $17-26$.
} 
institutions and, in addition, some commercial banks began to offer free checking accounts.

Thrift institutions have also been involved in a new system for making payments, called "pay-by-phone," which was initiated last fall by a savings bank in Connecticut and one in Minnesota. Under this system, depositors at these savings banks who open special interest-bearing accounts may make payments to third parties without writing checks or negotiable orders of withdrawal. Depositors use their telephones to make payments to utilities, merchants, and other organizations which participate in the system.

Approval by state banking authorities is necessary before such a system can be put into effect. Although the pay-by"phone system was judged to be illegal under Connecticut's existing statutes, the People's Savings Bank, Bridgeport, has been permitted to continue its pay-by-phone operations on a test basis until the end of 1975. At the same time, it was ruled that under the current provisions no other Connecticut mutual savings bank should be permitted to initiate such a system.

At the People's Savings Bank, depositors who open a special account are given a personal identification code number in addition to an account number. The customer can then dial a special telephone number and give these numbers to the operator who is told which companies and what amounts to pay. This information is transcribed by the operator, who tallies the total amount paid and informs the customer of the balance left in the account.

Minnesota is the only other state in which regulatory authorities have approved a pay-by-phone plan on a test basis. At the Farmers and Mechanics Savings Bank, Minneapolis, the pay-by-phone system operates either through an operator, as above, or by computer for those depositors with push-button telephones. With a push-button phone, the depositor indicates the amounts to be paid by depressing the corresponding telephone digits. The companies which participate in the Minnesota system, as well as those using the Connecticut system, receive daily printouts listing the name, account number and amount paid by every customer, along with a cashier's check issued by the savings bank for the total amount of payments.

\section{MVACR OF THE CHANGES}

\section{Adountages of Throfts h Compethe hor Deposity}

Until recently, thrift institutions have not provided commercial banks with much competition in offering checking account services. Although deposit accounts at thrifts pay interest, it is less convenient to make payments from these accounts than from checking accounts. With the recent changes in services at some thrift institutions, much of the inconvenience associated with making payments from saving accounts has been eliminated, thus making such accounts better substitutes for checking accounts at commercial banks.

Thrift institutions have had an advantage over commercial banks in two other important respects: maximum interest rates thrifts are allowed to pay and reserves they are required to hold. Commercial banks have been prohibited from explicitly paying interest on demand deposit accounts by legislation first enacted in the 1930s. ${ }^{5}$ Thrift institutions, on the other hand, have introduced accounts which approach de mand deposit accounts in function but which conveniently circumvent the interest rate prohibition on the accounts. Moreover, thrift institutions are permitted by law to pay higher maximum rates of interest on time and savings accounts than commercial banks may pay on comparable accounts. From the depositor's standpoint, interest rate regulations help make new accounts at thrifts more attractive than traditional checking accounts.

Although both thrift institutions and commercial banks are required to hold reserves against time and savings deposits, the amount and form of these reserves are different. Commercial banks are generally required to hold much larger reserve ratios than are thrift institutions. The amount of reserves thrifts are required to hold may be satisfied with earning assets; much of commercial bank reserves are held in a form that does not earn interest.

\section{Response by Commercial Banks and Weir Regulators}

The response of the banking sector to the changes initiated by thrift institutions has been varied. In general, independent commercial banking organizations

\footnotetext{
5This legislation was passed to prevent a recurrence of "excessive" interest rate competition which was thought to be an important factor in the large number of bank failures during the 1930 s.
} 
have forcefully opposed the changes initiated by the FHLBB, especially regarding the use of automated tellers and place-of-business terminals by savm ings and loan associations. Commercial bankers claim not only that they are competitively disadvantaged by the changes, but also that such piecemeal actions frustrate legislative financial reform now being advanced. If the new services are to be maintained at the thrifts, many commercial bankers say, then thrift institutions and commercial banks should be subject to equivalent reserve requirements and interest rate limitations.

The Comptroller of the Currency was the first Federal bank regulator to respond to the FHLBB's ruling on the use of remote service units by $S \& L s$. The Comptroller, whose office regulates national banks, issued an interpretive ruling in December 1974 concerning the use of off-premise electronic funds transfer terminals. The ruling permits national banks to operate Customer-Bank Communication Terminals (CBCTs) ${ }^{b}$ Through these remote terminals, existing bank customers can initiate transactions resulting in deposits to or cash withdrawals from their accounts, transfers of funds between checking and savings accounts, and payment transfers from their own accounts to accounts maintained by other bank customers.

In the ruling, the Comptroller stated that banks should be permitted to meet competition from savings and loan associations which have taken advantage of the new FHLBB regulations on remote facilities. It was specified in the ruling that CBCTs are not branch banks; a definition of these units as branch banks would have imposed on the banks geographic and capital restrictions which might have prevented them from meeting the competitive challenge posed by

\section{Exhbit II}

CBCT Nolifications filed with the Comptrollet of the Currency (Noy 30,1975 )

callomla

Bank of Anenica Mational.

31

supernarkets

rust ond Sorings Associotion:

San Fronciso

Colorodo

first Nathotal Bank, fort Collins

Horldo

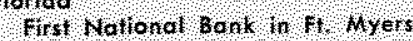

14

14

Sun First Moriondl Bank of leseburg

Georgio

$2 \%$

First Notiond Bonl of Atlanto

1

14

Ininols

Continentel Ilinols National $\iota_{\text {S }}$ ? A

Bank and Trust Company, Chicago

1,

$124 \mathrm{M}$

Mia Wert Klotiond Bank of

lake rorest

$1 \mathrm{n}$

lowa Des Noines National Bank

Minnetoto

Zcpp Nofional Bont, St, cloud

Missourt

fiest Nationd Bank in 5 , louts

Nebraska:

The Unifed Stales Natianial

Bonk of Omato

$3 \mathrm{M}$

14

1

2 h

H 1 s supertharkets:

I W

$2 \mathrm{~N}$ ४४ १ yef 10 be delermined

Oncho Kational Bank

$14 \mathrm{M}$ ४ 4 s supermorkets:

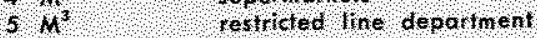

New lewor:

The National State Bank, Elizobeth

onlo

The Centrol Tust Conpany. Cheinnoll

Ollohona

First National Bank \& Trust

Compony of Eild

1 a

Unca National Bank, Tulsa

Oregon

United Stater National Bank

of Oregon, Portlond

Tennessee

Fint National Bant of Menphis:

Woshington

Peoples National Bank of

Wostington, Seatle

Seatfle first Nationol Bank

24

stores

Whsonsin

First Natonal Bank in

Menomonie

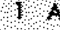

supernorkes

plont

14

shopping enter

$2 M$

shopping centers

14 ४ै shopping center

24

supetnatkess

$1 \mathrm{~A}$

5

1

shopping centers

bessiness distict

\section{A $\mathrm{A} \bullet$ stopping center}

$1 \mathrm{~A} / 2$ supertarket

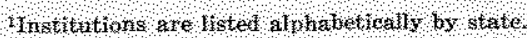

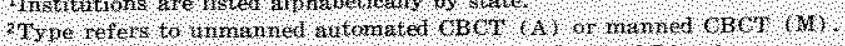

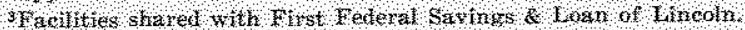

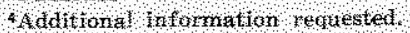

Cashltspensers onty

"The original December ruling sanctioned CBCTs without geographic restrictions. However, in a recent modification of this ruling, the Comptroller limited the location of CBCTs to within 50 miles of the main office or closest branch of a bank, effective June 1,1975 . The revised ruling permits exception to the geographic limit if the terminal is to be shared with one or more local depository financial institutions. the thrifts. Since CBCTs are not considered to be branches, a bank is required only to file a written 30 day notice with the Comptroller's office of its intention to install remote point-of-sale terminals or automated teller machines. No formal approval is 
required. Exhibit II presents a listing of CBCT notifications filed with the Comptroller of the Currency as of May 30, 1975.

The First National Bank in St. Louis was the first to make use of the Comptroller's ruling when it opened one remote facility at a supermarket and another at a factory in December of last year. Both CBCTs are located beyond the boundaries of the City of St. Lonis. Under Missouri law, facilities of St. Louis banks must be situated within the city limits. A legal controversy followed the installation of the CBCTs when the Missouri Commissioner of Finance filed suit against First National Bank claiming that by conducting banking business at sites other than those prescribed by law (within the city limits), First National Bank violates Missouri's branching statutes. First National Bank contends that CBCTs are communication devices, not branches, and as such are not subject to the state's branching law. The St. Louis bank defends its use of CBCTs on the grounds that they are necessary to meet the rising competition from the thrifts.

State authorities remain divided on the issue of CBCTs as branch banks. Oregon, Washington, and Massachusetts have authorized remote automated facilities through legislation and do not define them as branches. In Michigan, the Commissioner of the Financial Institutions Bureau ruled that antomated facilities are branch banks and therefore fall under Michigan's branching laws. The Attomeys General of Texas, Florida, and Kansas also have authorized the use of CBCTs in some circumstances, although branch banking is prohibited in these states. In Missouri, as in many other states, bills have been presented to the legislature which provide state chartered banks competitive equality with national banks in issues concerning the establishment of electronic terminals.

Other Federal bank regulators have advanced changes in an attempt to match in some ways actions taken by the FHLBB. The Federal Deposit Insurance Corporation (FDIC), the primary Federal supervisor of insured state banks that are not members of the Federal Reserve System, has proposed an amendment which would permit banks under its supervision to expand the scope of withdrawals made from savings accounts of depositors for the purpose of bill payment. Preauthorized withdrawals are currently sanctioned for the payment of charges related to real estate or mortgage loans. Under the proposal, a depositor may give the bank written authorization to make withdrawals from a savings account to meet a wider range of recurring obligations. The bank would make the payments either by a transfer of funds to the creditor's account or by drawing a check on itself payable to the creditor.

In a similar action, the Board of Governors of the Federal Reserve System has proposed permitting member banks to offer preauthorized bill payments from savings accounts of their depositors. These withdrawals could be used to pay any type of indebtedness to a third party and may be made by a transfer between accounts in the bank or by transmitting a check drawn on the bank to the creditor or to another bank for the account of the creditor. In addition, effective April 7, 1975, the Board of Governors authorized member banks to allow their customers to use the telephone to initiate withdrawals or transfers of funds from savings accounts. In revoking a policy in effect since 1936, the Board of Governors noted that security and technological improvements now make such telephone transactions safe.

\section{TMPrichens}

The larger scope of services now offered by thrift institutions represents an emerging trend toward closer alignment of deposit powers of thrifts with those of commercial banks. Thrifts have initiated services which have given these institutions an edge over commercial banks in competing for customers' deposits. Commercial banks have then made similar changes in order to maintain their competitive position.

For customers, this trend creates a greater number of alternatives for demand deposit services. Convenience of making financial transactions has been significantly increased, especially through the use of electronic funds transfer systems and telephone services. Nonpecuniary costs of transactions have decreased. With the new services, customers are able to have accotnts which approach the convenience and function of checking accounts and earn a higher rate of interest than on comparable accomts at commercial banks.

The more competitive financial system which is evolving is primarily the result of competitive forces set in motion by financial institutions which are striving to obtain customers' deposits. Some of the changes which have already been adopted by financial institutions have been included in financial reform legislation which has been proposed in recent years.

In 1970 the Presidential Commission on Financial Structure and Regulation (better known as the Hunt 
Commission) was appointed to study the framework of the nation's financial system and propose changes which would improve its functioning. Among other proposals, the Commission recommended expanding the power of thrift institutions and enabling them to offer limited checking account and credit card services. The proposed Financial Institutions Act of 1975 incorporates many of the proposals of the Hunt Commission and addresses itself to issues which have appeared since that time.

These proposals favor allowing thrifts and commercial banks to offer NOW accounts on a nationwide basis. In order to further competitive equality among different types of institutions, the proposals recommend phasing-out interest rate ceilings on all time and savings deposits and subjecting depository institutions to uniform reserve requirements. Indeed, if thrift institutions and commercial banks are becoming more similar in function, regulations governing the institutions should reflect these similarities. None of the reform proposals, however, has been enacted into legislation.

\section{CONCLUSION}

The move by thrift institutions to make savings accounts more convenient for making payments and thus more similar to checking accounts at commercial banks has intensified competition for deposits between the two types of institutions. Although legislation designed to achieve a more competitive financial system has failed to be enacted, competitive forces within the system are leading the financial institutions toward this end. It remains to be seen how the financial system will ultimately be affected by the changes taking place. In any event, these changes present evidence that competition remains an integral force in our financial system.

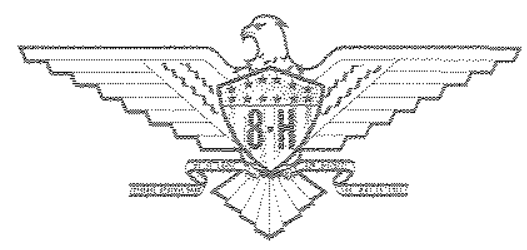

